«правильної відповіді немає» дозволяє значно ускладнити відгадування студентами правильних відповідей. Контролююча програма «Асистент 2» дає змогу об'єктивно оцінити рівень знань студентів як на екзамені, так і при самоконтролі. У випадку «прогалин» у знаннях студент звертається до навчального електронного підручника.

Висновки. Комп'ютерізація вивчення дисципліни «Деталі машин» дозволяє активно залучати студентів до навчального процесу, а також надає можливість зручного автоматизованого тестування в умовах кредитномодульної системи навчання.

\title{
Література
}

1. Завізена Н. Комп'ютерізація освіти з позиції психолого-педагогічного аспекту / Н. Завзена // Рідна школа, 1999. - №11. - С. 62.

2. Бугайов О. І. Концептуальні положення щодо розробки педагогічних програмних засобів із фізики / О. І. Бугайов // Комп’ютер у школі та сім’ї. - 2004. - №8. - С. 13-16.

Стаття надійшла до редакції 12.04.2012 р.

УДК $378.14+373.31$

I. В. Казанжи, кандидат пед. наук, доцент, Миколаївський національний університет імені В. О. Сухомлинського

\section{КОМПЕТЕНТНІСНИЙ ПІДХІД У ФАХОВІЙ ПІДГОТОВЦІ МАЙБУТНІХ УЧИТЕЛІВ ПОЧАТКОВИХ КЛАСІВ}

Казанжи I. В. Компетентнісний підхід у фаховій підготовиі майбутніх учителів початкових класів.

У статті йдеться про значення компетентнісного підходу у процесі підготовки майбутніх фахівців в умовах євроінтеграџійних прочесів; розкрито складові професійно-виховної компетениії учителів початкової школи.

Ключові слова: євроінтеграція, компетентнісний підхід, професійно-виховна компетентність, готовність до виховної роботи.

Казанжи И. В. Компетентносный подход в профессиональной подготовке будущих учителей начальных классов.

В статье раскрывается значение компетентносного подхода в прочессе подготовки будущих специалистов в условиях евроинтегращионных процессов; раскрыты составляющие профессионально-воспитательной компетентности учителей начальной школь.

Ключевые слова: евроинтергащия, компетентносный подход, профессиональновоспитательная компетентность, готовность к воспитательной работе.

Kazanghy I. The competent approach in the professional training of future elementary school teachers.

The article is devoted to the meaning of a competent approach in the future specialists' training under the conditions of Euro Integration process; the components of school teachers' professional educative competence are described here.

Key words: Euro Integration, competent approach, educative competence, readiness to the educational work.

Постановка проблеми. У реалізації вимог із запровадження «європейського змісту» освіти та програми дій щодо положень Болонської декларації в систему вищої освіти і науки України пріоритетного значення набуває втілення у вітчизняній освітній процес вищих навчальних закладів 
(ВН3) інноваційних форм навчання, серед яких - компетентнісний підхід. Вiн $\epsilon$ одним із концептуально важливих засобів управління якістю підготовки спеціалістів в Україні та світі.

Компетентнісний підхід - це спроба привести вищу освіту у відповідність 3 потребами ринку праці, запитами особистості й суспільства. Компетенції закладаються в освітній процес вищої школи технологіями, змістом, стилем життя навчального закладу, взаємодією між викладачем та студентом. Тому і підготовка спеціалістів у вищій школі України має визначатися саме якістю державних освітніх стандартів, навчальних планів i програм, моделей випускників, а також рівнем кваліфікації викладацького складу, рівнем навченості студентів, станом виховної роботи і матеріальнотехнічної бази та соціально-побутових умов студентів і викладачів.

Аналіз літератури (О. Абдуліної, О. Алексєєвої, Г. Арутюнової, К. Жукенової, Е. Іванової, О. Канапацької, Г. Кіт, Л. Нечаєвої, Р. Ню, Є. Палагіної, I. Порохової, В. Сагарди, В. Шутяката інших) дозволяє визначити підготовку вчителя як систему змістовно-педагогічних та організаційно-методичних заходів, що спрямовані на формування особистості майбутнього педагога на основі компетентнісного підходу.

Виховна діяльність учителя була предметом дослідження багатьох сучасних педагогів і психологів. В одних працях увага дослідників акцентується на змісті, формах і методах роботи. Цей підхід у розв'язанні проблеми реалізується в кількох напрямах: методології i методах дослідження проблеми (О. Григор'єва, М. Кузьміна), вивченні компонентів виховної діяльності і вмінь, які входять в неї (В. Сльманова, Г. Засобіна, С. Кисельгоф, Г. Метельський, Л. Соколовата інших), розв'язанні завдань у галузі виховання (А. Акімова). В інших працях об'єктом дослідження став процес формування професійних якостей вчителя як вихователя (Ф. Гоноболін, В. Сластьонін, О. Щербакова).

Визначення готовності до професійної діяльності подає Л. Григоренко. За словами автора, професійна готовність - це «сукупність професійнопедагогічних знань, умінь, навичок та особистісних якостей, що забезпечують результативність роботи шкільного вчителя» $[1$, с.41]. Однак дослідницею не визначено, які саме якості, знання, вміння, навички, що входять до структури готовності, не виокремлено ставлення до педагогічної діяльності.

Заслуговує на увагу дослідження А. Ліненко [2], у якому простежено історію поняття «готовності», здійснено глибокий аналіз сучасних досліджень з означеної проблеми. Готовність розглядається як цілісне утворення, що характеризує емотивно-когнітивну і вольову змобілізованість суб'єкта в момент його включення в діяльність певної спрямованості.

Автор указує на етапність у формуванні готовності майбутніх учителів до професійної діяльності: I - довузівська підготовка (педагогічні класи, профорієнтаційна робота у школі); II - основний етап, навчання у вищому навчальному закладі; III - професійна адаптація випускників педагогічних навчальних закладів. 
У низці досліджень (І. Богданова, Л. Заремба, М. Козак, О. Мороз та інші) запропоновано розглядати структуру професійно-педагогічної готовності майбутніх фахівців як цілісне утворення особистості, що включає три компоненти: мотиваційний, оцінний, операційний.

Професійне становлення вчителя-вихователя в динаміці розглядається в педагогічній літературі на таких рівнях: інтуїтивному, репродуктивному, репродуктивно-творчому, творчо-репродуктивному, творчому (В. Сластьонін), в основі кожного з яких - відповідний рівень готовності випускника вищого педагогічного закладу до виконання своїх виховних функцій.

Як свідчить аналіз проведених досліджень, вивчення виховної діяльності вчителя початкових класів здебільшого проводиться 3 функціональних позицій. Це знаходить вираження і у трактуванні сутності виховної діяльності. Системний аналіз передбачає, що виховна діяльність розглядається як цілісний об'єкт дослідження, причому головну увагу приділено не окремим іiі елементам, а тим взаємозв'язкам, які конструюють систему діяльності, є ії суттєвими характеристиками.

Питання цілісності підготовки вчителя підіймає у своєму дослідженні 3. Курлянд [3]. Цілісність підготовки вчителя передбачає таку організацію навчально-виховного процесу, при якій стимулюється активний стан усіх структурних компонентів особистості майбутнього вчителя у їх єдності. Це $є$ можливим, якщо навчально-виховний процес, спрямований на підготовку майбутніх учителів, залучає студентів до різноманітних видів діяльності, які допомагають засвоїти не лише необхідні знання зі спецпредметів, а й розвивають педагогічні здібності і вміння, творчий потенціал, формують навички управління своїми психічними станами.

Готовність до педагогічної діяльності в загальних рисах характеризує $\mathrm{i}$ готовність до виховної позакласної та позашкільної роботи, яка має і свої особливості, зумовлені специфікою виховної роботи.

Аналіз літератури 3 проблеми професійно-педагогічної підготовки дозволив виявити взаємозв'язок виховної діяльності вчителя початкових класів із процесом його підготовки та станом готовності до її здійснення. Він виявляється в наступності та взаємозумовленості функцій цих педагогічних систем (підготовка $є$ засобом формування готовності до діяльності, готовність $\epsilon$ результатом і показником якості підготовки і реалізується та перевіряється у діяльності; діяльність є метою підготовки та водночас виконує функції іiі регулювання й корекції), а також у відповідності їх структурних компонентів.

Н. Кузьміна виокремлює п'ять таких структурних компонентів системи педагогічної діяльності: суб'єкт і об'єкт педагогічного впливу, предмет їх спільної діяльності, мета навчання і виховання та засоби педагогічної комунікації, що пов'язані між собою прямими й зворотніми зв'язками. До функціональних компонентів означеної системи Н. Кузьміна відносить: гностичний, проектувальний, конструктивний, комунікативний і організаторський $[4$, c.5].

Розвиваючи погляди Н. Кузьміної і враховуючи кільцеву структуру діяльності, О. Дубасенюк виокремлює такі компоненти (етапи) виховної 
діяльності: 1) діагностувальний; 2) проектувально-цільовий; 3) організаційний; 4) стимулюючо-спонукальний; 5) контрольно-оцінний [5, с.91].

Отже, професіоналізм виховної діяльності педагога - інтегральна властивість, що водночас означає і процес, i результат творчої діяльності, концентрований показник особистісно-діяльнісної сутності вихователя, зумовлений мірою реалізації його моральної зрілості, відповідальності, професійного обов'язку.

Як свідчить практика, труднощі професійного становлення студентів пов'язані 3 осмисленням навчально-виховних проблем, що виникають унаслідок пошуку адекватних форм i методів педагогічного впливу, обгрунтованого педагогічного рішення. Для успішного виконання професійних функцій учителю необхідні високий рівень теоретичних знань, творче професійне мислення і грунтовний багаж загальної культури.

Готовність до виховної роботи передбачає як обов'язковий компонент потреби фахівця у професійному самовдосконаленні. По-справжньому освічений вихователь - це той, хто відчуває потребу постійно поповнювати свої знання, розвивати свої розумові здібності, вміє всебічно користуватися своїми інтелектуальними і творчими можливостями, професійними навичками.

Професійно-педагогічна компетентність у царині виховання визначається вмінням педагога особливим чином структурувати наукові i практичні знання для ефективного розв'язання виховних завдань. Особистісні знання в такому разі $є$ результатом розвинених здібностей i спрямованості, що впливають на сприйняття педагогічних явищ, ситуацій, а також на способи їх перетворення $з$ наукових позицій.

Професійно-педагогічна компетентність, що є показником підстуктури професіоналізму особистості педагога-вихователя,- складне утворення. До основних елементів О. Дубасенюк відносить такі: 1) компетентність у галузі теорії і методики виховного процесу, зокрема його цілей, завдань, принципів, закономірностей, змісту, засобів, форм, методів, прийомів; 2) компетентність у галузі фахових предметів і знання того, як зробити процес навчання, зміст предмета провідним засобом виховання учнів; 3) соціально-психологічна компетентність у галузі процесів спілкування; 4) диференціальнопсихологічна компетентність у сфері мотивів, здібностей, спрямованості учнівської молоді; 5) аутопсихологічна компетентність у царині достоїнств і недоліків власної діяльності і особистості. Зріла, сформована особистість педагога-вихователя - професійна необхідність, що зумовлена процесом пошуку способів формування особистості вихованця [5, с. 95].

Поняття «професійно-педагогічна компетентність» уперше було введено до наукового обігу Н. Кузьміною [4, с. 119]. Автор так визначає професійно-педагогічну компетентність (педагога за фахом): це «сукупність умінь педагога як суб'єкта педагогічного впливу особливим чином структурувати наукове і практичне знання задля найкращого розв'язання педагогічних завдань» [4, с. 90]. 
Під виховною педагогічною компетентністю ми розуміємо єдність теоретичної, практичної, особистісної готовності майбутніх педагогів до здійснення виховної діяльності з молодшими школярами.

Готовність учителя початкових класів до позаурочної виховної роботи це складне інтегроване поняття, що передбачає єдність теоретичної, практичної і морально-етичної підготовки майбутнього вчителя початкових класів до здійснення всіх видів виховної діяльності 3 учнями в позанавчальний час, установлення творчих зв'язків із різноманітними позашкільними закладами у справі виховання молодших школярів.

Кінцевим результатом готовності студентів до позаурочної виховної роботи, на наш погляд, є професійно-виховна компетентність, яка обіймає такі чинники (види компетенцій): когнітивно-виховна (у галузі теорії i методики виховного процесу, в галузі фахових предметів); конструктивновиховна (в галузі процесів прогнозування, планування); регулятивно-оцінна компетенція (самооцінка своєї підготовленості, рівня вихованості, визначення шляхів професійного самовдосконалення).

3 урахуванням означених чинників професійно-виховної компетентності вчителя початкових класів нами було визначено критерії і показники готовності майбутнього вчителя молодших класів до виховної роботи в позаурочний час.

Отже, професійно-виховна компетентність, готовність майбутніх учителів до здійснення позаурочної виховної роботи із молодшими школярами обіймає такі критерії, як когнітивно-виховну (вміння визначати напрямки позаурочної виховної роботи, вміння добирати форми і методи позаурочної виховної роботи, вміння добирати адекватні методики позаурочної виховної роботи), конструктивно-виховну (вміння планувати позаурочну виховну роботу і складати сценарії, вміння аналізувати результати здійснюваної позаурочної виховної роботи), регулятивно-оцінну (вміння адекватно оцінювати свою виховну компетентність, контролювати i критично аналізувати результати виховної роботи, визначати шляхи професійного самовдосконалення, самовиховання) компетенції.

За висновком Г. Троцко, нині існує чимало концепцій підготовки студентів педагогічних навчальних закладів до виховної роботи у школі. Це концепції: комплексного підходу, професійно-діяльнісного, інтенсифікації навчально-виховного процесу на основі цільового підходу, цілісності, цілісного «бачення» педагогічного процесу, виховання особистісної культури вчителя, формування педагогічної майстерності через спеціальні вправи в контрольованих умовах, професіоналізації поза аудиторної роботи 3 педагогіки [6, с.91].

На думку науковців, які досліджують питання теорії і методології професійної підготовки, пріоритетною формою розвитку системи освіти повинно стати створення інтегративних курсів, що віддзеркалюють динамізм сучасної наукової парадигми, багатогранність ії внутрішніх взаємозв'язків. Нині у структуруванні знань має використовуватися принципово інший підхід, а саме - філософська інтеграція різнорідних галузей знань і окремих 
теоретичних систем, позицій на природу людини, суспільство (С. Гончаренко, Ю. Мальований) [7].

Висновки. Отже, в умовах значно зміненого соціально-політичного та екологічного середовища до майбутнього вчителя висуваються більш широкі вимоги. Це не тільки володіння обсягом загальнонаукових і спеціальних знань, який постійно збільшується, але й моральна чистота, вимоглива доброта, душевна щирість, любов до дітей. Усе це має професійний статус. Успіх реалізації усіх ланок педагогічної підготовки студентів визначається впровадженням у практику навчання нових підходів до його організації і сучасних педагогічних технологій. Розробляючи і впроваджуючи нові технології у навчальний процес педагогічного університету, слід подбати про те, щоб змінити ставлення студентів до педагогічної роботи, стимулювати позитивну мотивацію i прагнення займатися позаурочною виховною роботою з повною віддачею сил і творчості, забезпечити ситуацію успіху для кожного студента.

\section{Література}

1. Григоренко Л. В. Формирование готовности студентов педвуза к профессиональной деятельности в процессе самостоятельной работы : дис... кандидата пед. наук : 13.00. / Л. В. Григоренко. - Кривой Рог, 1991. - 162 с.

2. Линенко А.Ф. Теория и практика формирования готовности студентов педагогических вузов к профессиональной деятельности. - дис. ... доктора пед. наук: 13.00.0 / А. Ф. Линенко. - К., 1996. - 412 с.

3. Курлянд 3. Н. Формирование и развитие профессиональной устойчивости учителя : дис... канд. пед. наук : 13.00 .04 / 3. Н. Курлянд. - Одеса, 1992. - 193 с.

4. Кузьмина Н. В. Профессионализм личности преподавателя и мастера производственного обучения / Н. В. Кузьмина. - М. : Высшая школа, 1990. -119 с.

5. Дубасенюк О.А. Концептуальні положення теорії професійної виховної діяльності педагога / О. А. Дубасенюк // Педагогіка і психологія. - 1999. - № 4. - С. 91.

6. Троцко Г. В. Професійно-педагогічна підготовка студентів до виховної роботи в школі / Г. В. Троцко. - Харків, 1995. - 184 с.

7. Гончаренко С. У. Інтегроване навчання: За i проти / С. У. Гончаренко, Ю. І. Мальований // Освіта. -1994. - 16 лютого. - С. 2-3.

Стаття надійшла до редакції 14.05.2012 р.

УДК 37.013 .8

Т. О. Дороніна, кандидат пед. наук, дочент, Криворізький педагогічний інститут ДВНЗ «Криворізький національний університет»

\section{ДОСВІД КРАЇН ЗАХІДНОЇ ЄВРОПИ ТА ПІВНІЧНОЇ АМЕРИКИ ЩОДО ЗАПРОВАДЖЕННЯ ГЕНДЕРНОЇ ОСВІТИ В НАВЧАЛЬНИЙ ПРОЦЕС}

Дороніна Т. О. Досвід країн Західної Європи та Північної Америки щэодо запровадження тендерної освіти в навчальний прочес.

У статті висвітлено практику впровадження тендерної теорії в систему освіти Західної Свропи та Північної Америки; окреслено можливості використання прогресивного досвіду розв'язання досліджуваної проблеми в освітніх закладах Украӥни.

Ключові слова: гендерна теорія, практика гендерної освіти, теоретичний та педагогічний аналіз. 